\title{
Hospitality, ethics of care and the traditionist feminism of Beit Midrash Arevot
}

An experiental essay

DOI: https://doi.org/10.30664/ar.94926 (c)( Attribution 4.0 International (CC BY 4.0)
$\mathrm{T}$ his is an exploration of women's tradition of hospitality, the epistemic and moral contribution of their practices of welcoming the other and their historical experience as providers of care. The essay claims that female hospitality has largely consisted of care for others, which challenges a social model based on individualism and self-sufficiency. The argument is rooted in ethnography and Jewish thought and reclaims the home as an ethical space. This text analyses two disturbing and painful stories from the Tanakh that are both examples of the consequences of extreme or absolute hospitality and violence against women. The famous works of Jacques Derrida and Emmanuel Lévinas on hospitality as ethics and hospitality as the feminine are discussed vis-à-vis anthropological and feminist approaches to the connection between the female welcoming of the other and the ethics of care. Finally, the reflections of the members of Beit Midrash Arevot (Jerusalem) shed light on a traditionist feminism that develops an ethics and practice of hospitality as welcoming otherness.

La mujer en el cante jondo se llama Pena ${ }^{1}$ Federico García-Lorca

1 An approximate translation of this quote would be 'Pain is the name of woman in cante jondo.' Cante jondo is an ancient kind of singing developed in Andalusia. This kind of ancient singing, which at times resembles a scream, a cry and a lamentation, is the theme of a famous lecture given by Federico García-Lorca in 1922 called 'The historical and artistic importance of the primitive Andalusian cante jondo.

\section{Introduction}

This essay is an examination of the argument I first shared at the symposium 'Feminism and Hospitality: Religious and Critical Perspectives in dialogue with a Secular Age'2, in which I explored Jewish sources in the search for a women's perspective on hospitality. The sources of this essay have different origins: the Tanakh ${ }^{3}$, feminist biblical criticism, Jacques Derrida's and Emmanuel Lévinas's writings on hospitality, anthropological research on the domestic space and women's rituals, and South-American decolonial feminism,

2 The symposium 'Feminism and Hospitality: Religious and Critical Perspectives in dialogue with a Secular Age' took place in Turku, organized by the Nordic Summer University in collaboration with Åbo Akademi University, Polin Institute and the Donner Institute for Research in Religion and Cultural History, which generously invited me as one of the keynote speakers. I am indebted to all the speakers and attendants for the countless conversations we had during those three days. I came out of this encounter filled with ideas about the importance of a feminist critique of Western models of autonomy. This essay is the result of those reflections.

3 Tanakh: an acronym of Torah (Pentateuch), Nevi'im (Prophets) and Ketuvim (Writings). It is also called the Hebrew Bible. 
among others. However, the most critical source of all is the ethnographic material I have collected through interviews, informal conversations and group discussions I have been part of along with other women who inhabit my 'epistemic communities. The ethnographic material I am presenting is the result of a collaboration in which friends, colleagues and members of my communities have become epistemic partners (see Estalella and Sánchez-Criado 2018) in the experience that I am translating here.

More specifically, my argument is inspired and informed by my participation in a women's group called 'Arevot women weaving tradition'. In 2018 I started conducting an ethnography of this space while I was a member and active participant. Arevot is a group, a movement and a Sephardi ${ }^{4} /$ Mizrahi $^{5}$ feminist Beit Midrash 6

4 Sephardi Jews originate in the Iberian Peninsula and were expelled in the fifteenth century, arriving in the north of Africa and the Ottoman Empire, among other places.

5 Mizrahi means 'Eastern' or 'Oriental' and it is a socio-political category used in Israel to designate all Jews who are not of European descent, mostly, Jews from north African and Middle Eastern descent. Mizrahim (plural of Mizrahi) constitute more than half of the Jewish population of Israel and have been heavily discriminated against.

6 A Beit Midrash is a space devoted to the study and interpretation of the Jewish textual tradition. It is also a learning methodology through dialogue, in hevruta, with a learning partner, using close reading and interpretation. It has traditionally been reserved for men. Today there are several Batei Midrash (plural) that accept women and others that are only for women. The main books to be found one the bookshelves of a Beit Midrash are the Tanakh, Talmud, Midrash (commentary), mystical texts, translations, codes of Jewish law, analytical works of different eras, philosophy, commentaries and responsa. Students work in groups, usually in pairs (hevruta) with
(House of Study). In this space we explore different texts: Sephardi/Mizrahi rabbinic responsa, parts of the Talmud that deal with issues of social justice, as well as texts written by Sephardi/Mizrahi female Torah scholars and intellectuals. The women of Arevot also recover and preserve rituals that have been passed on from generation to generation, from mother to daughter, and reclaim them as a bridge between our world and the world that preceded us. These rituals are a link between our own ideas and principles and the protective shelter of our customs and collective imaginary. They are our reference system about life stages, biological cycles, the passing of our loved ones, the birth of children, the change of the seasons, and the changes in our roles and functions, and so on. My perspective is informed, based on, and inspired by the resistance of this group, a resistance that 'interrupts' various established narratives: the Western feminist narrative, the patriarchal narrative and the narrative of modernity. ${ }^{7}$

There are moral, literary and philosophical traditions that emerge from the specificities of the historical experience of women. Memories, rituals, practices of care, as well as the timing and pace of the interior - as opposed to the traditionally masculine exteriority - have been passed on amongst women from generation to generation. As Haviva Pedaya (2019) has claimed, there is a civilization - with countless different cultures and specificities - constituted by women whose story is still looking for a language in which it can be told.

their learning partner and decipher and interpret the texts. Teachers and students work together on the textual exegesis, logical analysis and argumentation.

7 I have borrowed from Yuderkys Espinosa the idea of a resistance that 'interrupts' the establishment's narrative. See Barroso 2016. 
Between the patriarchal reclusion of the woman-mother in the privacy of the home that appears in the Biblical narrative, and the post-modern deconstruction of the very category of 'woman', emerge female traditions of hospitality and ethics of care that deserve epistemic authority, beyond the critique of oppression. South American decolonial feminists have articulated our obligation, as social researchers, to approach the diversity of female experiences not only as objects but as alternative epistemological and moral models:

The subject 'women', as a political category, articulates specific locations, concrete materialities, as well as diverse memories and histories of subordination, but also multiple experiences of resistance and struggle. It is within this diversity of experiences that feminisms contribute emancipatory visions that transcend the mere liberal framework of rights. (Sagot Rodríguez 2017: 10, my translation)

\section{Biblical hospitality as a male ritual: protocol, politics and honour}

The practice of hospitality as described in the Tanakh is a prerogative of men (Gudme 2019). Women provide the labour of hospitality - washing, cleaning, cooking, preparing, etc. - but they are not agents of it, that is, they do not have the authority to offer hospitality. To put it simply, women in the Tanakh are not supposed to invite strangers into the house. There are a very few instances of female hospitality - an invitation to take shelter and/or to eat and drink - in the Hebrew Bible; for example, Esther, Yael and Judith, and none of them has a good ending for the guest (Duran 2005). Rather, women identify a vulnerability, a stranger in need of shelter and food, and report it to the father or the husband, the male head of the family. Two canonic examples of this are Rebecca meeting Abraham's servant (Genesis 24) and Rachel meeting Jacob for the first time (Genesis 29). It is the head of the family who then approaches the stranger and offers hospitality. Male hospitality offers refuge and protection. Female hospitality appears as attentive to vulnerability and need, sheltering and nourishing. Female hospitality is domestic. In fact, to put it in Levinasian terms, it is the very condition of the domestic sphere.

Hospitality in the Tanakh is comparable with hospitality practices across the Mediterranean and the Near East (see PittRivers 1968). It functions according to the following protocol: both individuals, and villages or towns, have a responsibility to offer hospitality to the stranger. It is a practice that ensures cohabitation and commensality, which creates a bond between host and visitor and transforms a stranger and potential threat into a friend and possible ally. As indicated before, it is the prerogative of the male head of the household, or a male citizen, to offer hospitality (Gudme 2019; Matthews 1991). Therefore, a sojourner or ger cannot extend hospitality, as it would reflect badly on the village. The host typically states in his offer of hospitality a defined time span, which could be extended according to the circumstances, with a renewed invitation. The stranger has the right to refuse, although this could be considered an insult and thus result in hostilities. Once he accepts the invitation, the guest must not make requests. The host will provide the best of what he has, which often exceeds what he initially offered. The guest reciprocates with gifts, good wishes, good news, expressions of gratitude exalting the host's generosity. The host must not ask personal questions, no matter what the guest's origin may be, and information is revealed at the guest's will. The host is 
under an absolute obligation to protect the guest. It is the host's responsibility to ensure the safety and well-being of the guest (for an in-depth analysis of this pattern, see Matthews 1991). Hospitality is a practice that initiates a cycle of reciprocity (Gudme 2014). Finally, it entails a risk, as the guest might harm the family, or others might try to harm the guest, which puts the host in the position of having to do everything in his power to protect him.

Hospitality in societies like the one described in the Tanakh, is a ritual fulfillment of obligation and expectation (Matthews 1991). Hospitality turns the unknown, the foreign and potentially threatening stranger into an intimate, familiar, friend and a potential ally with obligations of reciprocity. This transformation happens on two levels: on a symbolic level the unknown is coming into the terrain of the intimate and familiar. On the level of custom, tradition and law hospitality makes the guest indebted to the host, who gains his loyalty and future protection. A breach in the laws of hospitality entails the collapse of the very possibility of finding shelter, of transforming hostility into protection. The practice of hospitality is connected to the question of safety and preservation of life, and it originates in the need for aid when away from home (ibid.).

In other words, this model of hospitality functions in a legal sphere; in the public/political space where the law governs. Offering hospitality is a right and a responsibility. That is the reason why a resident alien, or a sojourner, or a woman cannot offer hospitality. It is strongly based on reciprocal obligations among men that increase survival chances. The figure of the guest binds the individual and the community to the stranger, granting him a status 'midway between that of the hostile stranger and that of the community member.
$\mathrm{He}$ is incorporated practically rather than morally' (Pitt-Rivers 2017b: 166). There is an inherent tension in this ritual of hospitality among men:

The law of hospitality is founded upon ambivalence. It imposes order through an appeal to the sacred, makes the unknown knowable, and replaces conflict by reciprocal honor. It does not eliminate the conflict altogether but places it in abeyance and prohibits its expression. (Pitt-Rivers 2017b: 178)

Hospitality as described above is the opposite of intimacy or familiarity. Hostility 'is always lurking beneath the surface of hospitable relations' (Pitt-Rivers 2017a: 94), being a main characteristic of this practice. This is, at least, the male experience of hospitality, based on reciprocity, obligation and honour. I will argue that this model of male hospitality is political, while the model of hospitality historically developed by women - welcoming others in their home - opens a space to the ethical.

\section{The collapse of hospitality: two biblical narratives of brutality}

At the end of his book Of Hospitality (2000), Derrida mentions two painful biblical stories which describe a violation of the safety which hospitality is supposed to guarantee: Genesis 19 and Judges 19 (for an analysis of the commonalities between these two narratives see Matthews 1992). Derrida is not clear about the significance of these two stories for the argument he is making, but asks the reader to think about the invariant elements of the two narratives. These are stories that represent the patriarchal model of the father, the husband, the familial despot, the master of the house. As Derrida says, this model of man lays down the laws 
of hospitality. He represents them and submits to them to submit the others to them in this violence of the power of hospitality' (Derrida 2000: 149).

My recounting of these stories will serve the purposes of my argument only. A complete and in-depth understanding of both stories would require an analysis and commentary that are beyond the purposes of this work. I therefore invite the reader to read the full version these stories in their full extension and complexity from the Tanakh.

The first is the story of Lot and his daughters, which appears in Genesis 19. Lot, Abraham's nephew, lives as a sojourner or ger in Sodom, which is about to be destroyed by God due to the immorality of its people. Two strangers - who are actually two angels - approach Lot's house and he offers them hospitality, even though he has no right to represent the city and offer hospitality, since he is not a citizen (Matthews 1992). All the of men of Sodom - old and young, says the narrative, indicating that the whole city is there and there is not a single righteous person (ibid.) - appear in front of Lot's house and demand that he brings out the foreigners so that they can rape them. Lot begs the mob to not harm his guests and offers his two virgin daughters to the mob in exchange. The men push Lot against the door, coming close to breaking into the house. At this point, the two strangers reveal their divine nature and blind the mob, giving Lot and his family the opportunity to escape.

The second story appears in the Book of Judges, chapter 19 and it is among the most disturbing stories in the Tanakh. It is a particularly complex story whose full explanation and analysis exceeds the aim of this essay. I will summarize it for the purposes of my interests here, at the risk of leaving out information that may seem critical in the eyes of an expert reader. Chapter 19 of the Book of Judges tells the story of a Levite and his concubine (some interpreters claim she was his wife), who are on their way home from the concubine's father's house. They arrive at the town of Gibeah, located in an area that belongs to the tribe of Benjamin. It gets dark and nobody offers them hospitality. They are sitting in the town's square and still nobody comes to greet them and offer them shelter, which is a sign that portends something terrible. An old Ephraimite, a sojourner or ger with no right to represent the city, appears and invites them to sleep in his house. The Levite makes sure to tell him that they only need a roof to sleep under, since they already have provisions for themselves and their donkeys. This declaration of self-sufficiency is already a violation of hospitality rules (Matthews 1992). A group of men show up at the old Ephraimite's house and demand that he brings out the foreigner so they can rape him. The Ephraimite begs them not harm his guest, and the man's daughter and the Levite's concubine are offered instead. The mob takes the Levite's concubine and rapes her until sunrise. After having been brutalized for hours, the woman walks towards the Ephraimite's door, where she collapses on the floor and dies. The Levite comes out of the house, takes her, puts her on the donkey and heads home. Once in his house, he carves the woman's body up in twelve pieces and sends one piece to each of the tribes of Israel. Appalled, the Israelites gather at Miztpah to hear the Levite's story and plan a response to the Benjamites, which triggers a cycle of violence that almost wipes out the entire tribe.

The 'terror story' of Judges 19 (Trible 1984) appears in the context of the absolute chaos that reigned before the establishment of monarchic rule among the Israelites. According to Norma Joseph the entire 
book of Judges can be analysed through the treatment of women, in the sense that the degeneration in the treatment of women coincides with the degeneration of the whole society that Judges narrates. ${ }^{8}$

After reading these stories, one is burdened with the task Derrida gave us as readers, to figure out whether we are, in any sense, heirs to this tradition of 'absolute hospitality' and, if so, what are we supposed to do with the violence and brutality contained by such tradition. Responding to Derrida's question about the common elements between these two narratives requires taking a step back. Both stories take place in the context of a world that is on the cusp of being turned upside down: ${ }^{9}$ Sodom is about to be destroyed as punishment for their depravity and, in the case of Judges 19, the moral anarchy of tribal leadership is soon to give way to monarchic rule. The violation of the home as a sheltering and safe space, with the consequent violence against women, tends to appear in the Tanakh when the world is either collapsing, or about to collapse (Gudme 2014). In both cases, the brutality towards women signals the destruction and descent into moral depravity of the society. Women are used as men's property and the narrative does not show particular interest in them, which is a tendency of later commentaries as well. However, the rabbinic tradition (specially the Tosefta ${ }^{10}$ and the Babylonian Talmud) puts the experience of the concubine at the forefront, calling the Levite into question

8 Personal communication with Norma Joseph, Concordia University, Montreal, 27.2.2020.

9 Personal communication with Rabbi PierPaolo Punturello, 3.2.2020.

10 Tosefta: literally 'addition' or 'supplement', a compilation normative (halakhic) and narrative (aggadic) traditions not included in the Mishna.
(Sanders 2004) ${ }^{11}$.

What are we, the alleged heirs of this tradition, to do with the stories of these unnamed women who pay the price of the collapse of men's hospitality? I contend that the social corruption that leads to the violation of the commandment to take responsibility for the stranger is expressed in the narrative by the cancellation of the home as a sheltering space. This space of refuge has historically been female, and its violation is tantamount to the destruction of the values women have represented, summarized in their ethics of care:
The position of women in the tradi- tion of the Mediterranean has, for all its variation, at least this constant: that they are viewed always in opposition to the world of men to which they are both essential for moral as well as practical reasons and yet contrary in terms of the values they symbolize (Pitt-Rivers 2017C: 191).

My claim is that there is a tradition of female hospitality that speaks about the relation between welcoming the other and the complex reality of life, that demands more than protocol, that enacts a high tolerance of ambiguity and flexibility. This is a tradition - a long history of conceptualizations and practices - born in the domestic sphere. This tradition, grounded in the mothering experience of care, is programmatically opposed to violence (see Ruddick 1995) and demands a social transformation based on flexibility, responsibility,

11 The examination of the representation of this story in the translations, retellings, and rabbinic discussions of Judges 19 that date from the Common Era to the end of the Classical Rabbinic Age, has been the object of the remarkable work of Jennifer Sanders (2004). 
compassion, and care. In the following lines I will attempt to establish the coordinates of such a tradition and its expression in the culture created by the women of Arevot.

\section{Women inhabiting the border zone: a transition into a different territory}

As we have seen above, in societies like the one described by the Tanakh, the host's act of invitation takes place outside the house, in the public sphere, where solidarity, reputation, status, authority and social relations occur. The host-guest relation follows a strict protocol. But it is by encountering the woman of the house that the stranger becomes the guest, in so far as he crosses the threshold that separates the interior space of the home from the outside world.

Despite its being a male ritual whose purpose is to curb the stranger's potential threat, hospitality in fact takes place in the space of the home. Hospitality entails coming into contact with the woman of the household who, in turn, provides labour which indeed is nothing less than care: feeding, cleaning, nurturing. The guest is a protected person and the woman provides care. In other words, hospitality - the welcoming of the other - and the home are two closely connected experiences for women. The stranger's incursion into the private sphere makes him a beneficiary of care. In this sense, I claim that the welcoming of the other as care for the other is a female contribution to human ethics.

The interiority of the house in which the guest is sheltered is the feminine space par excellence. The inner quarters of the house are the prime space where familiarity and intimacy happen. Nonetheless, there are hardly any descriptions of the interior of the house in the Tanakh (Gudme 2014) - in contrast to extensive descriptions of geographic terrain and sacred spaces of worship. The striking absence of

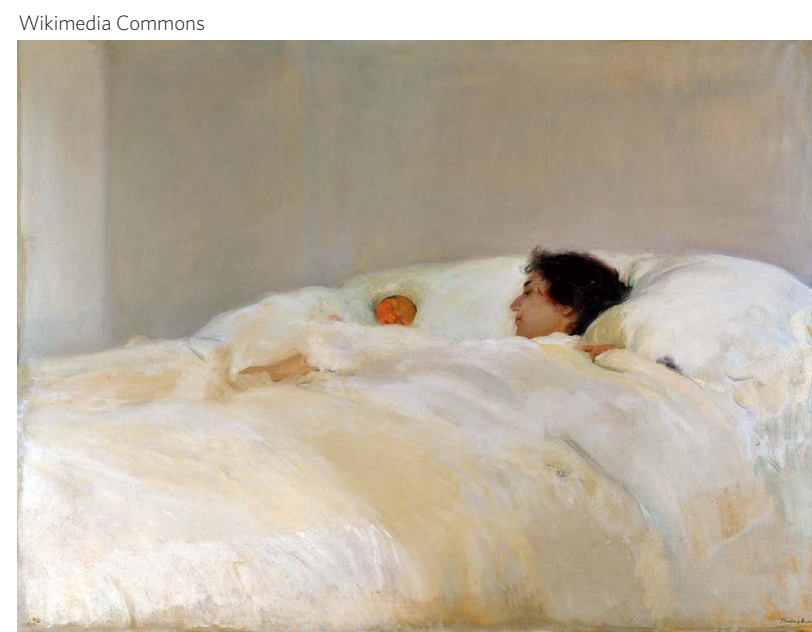

Madre, 1900. Joaquín Sorolla (1863-1923). Sorolla Museum, Madrid.

a representation of the domestic/female space is indicative of the general absence of a representation of the reality of the female in her own terms.

In Mediterranean societies, women appear as 'not merely mysterious, opposed to males upon the moral plane, but on the social plane "out of bounds," segregated and surrounded by taboos' (Pitt-Rivers 2017b: 191). These mysteries and taboos include sex, childbirth, impurity and contact with the dead. Hélène Cixous writes that 'men say that there are two unrepresentable things: death and the feminine sex. That is because they need femininity to be associated with death' (Cixous 1976: 885). To be unrepresentable is to be obscure, unrelatable, hardly present.

Femininity has indeed been associated with death (see Madar 2014). Also, the liminal spaces between life and death, the public and the domestic, the human and the divine, seem to have been privileged spaces of female presence and action across the Mediterranean and the Near East. In fact, Galit Hasan-Rokem's study of the Book of Lamentations has shown how women have been 'assigned to scout the borderlands between the known and the 
unknown, life and death' (Hasan-Rokem 2014: 48). In this work, Hasan-Rokem presents the inseparable connection between laments and motherhood. Lamentations are a universally female genre with an inherently subversive component in that the lamenter challenges the divine forces, therefore inhabiting a risk zone that men have often preferred to avoid, with the exception of prophets (ibid.). Likewise, Vered Madar, in her research about lamentation rituals among Yemenite women, says that the house where women perform the lamentations becomes a liminal space outside of the social order and, at the same time, bound by it. Because of their main role in death rituals (cleaning the body, preparing it for burial, lamenting), women become a part of the 'death space' almost permanently (Madar 2014: 67). Through their lamentations, charged with questions asked to the deceased about what they eat, whether they are warm or cold, a continuity between life and death is implemented, as if the deceased were going to inhabit a world parallel to the one we live in. This facilitates a relationship between the deceased and those left behind (ibid.).

Birthing, nursing, caring, lamenting: the cycle of birth, nurture, and death, has been embodied by women and expressed in the tasks they have traditionally held. All these practices have been regarded as having no epistemic nor ethical content, let alone authority. Visiting holy tombs, praying for the well-being of their loved ones, lighting candles for the festivities to mark the transition into a holy time, preparing special food for Shabbat and festivities, the creation of life-cycle rituals, ceremonies against the evil eye, their work as midwives, their command of all the rules of kashrut ${ }^{12}$,

12 Kashrut: Jewish dietary laws. their repertoire of blessings sought by the younger generation, their mourning rituals, women's domestic religious healing rituals. Romances or songs sung by women at weddings, pre-wedding rituals, festivities, celebrations. Women as bearers of communal memory, tales told by women, sayings, blessings. Many of these practices have a strong subversive component and they were either disliked, discredited or even forbidden: for example, their visits to holy tombs, their invocations against the evil eye (see Starr-Sered 1990), the contact with the dead and some aspects of the lamentations (Madar 2014) or their singing tradition (Elbaz 2018).

These practices of Jewish women's traditional religiosity have been intensely relationship oriented (see Starr-Sered 1992). Women have carried the weight of and taken responsibility for the community's need for care, nurture, healing, memory, protection, mourning and lamenting. It is not by chance that, in a different cultural context, South American decolonial feminism has both tried to defend the legitimacy of women's knowledge alongside a recuperation and preservation of traditions that have resisted modernity and neoliberal values.

To produce and make visible our interpretation of the world as a priority in the processes of decolonization. A task that must be accompanied by the traditions of knowledge that, in Abya Yala $^{13}$, have resisted the attack of coloniality. (Espinosa-Miñoso 2014: 8, my translation)

13 Abya Yala: word in Kuna (current Colombia and Panama) language which means 'mature land' or 'flourishing land' and is synonymous of America. 
If we accept that hospitality is the institutionalization of our responsibility for the other's vulnerability, it will become more clear about how the female practices I have just mentioned describe the parameters of their provision of care for those vulnerabilities. Those are the parameters of the female territory where ethics of care emerge.

\section{Welcoming the other: the home as an ethical space}

The model of female hospitality I attempt to explore here is in fact a 'performative extension of care ethics' (Hamington 2010: 24). The ethics of care is a historically female contribution and, as Carol Gilligan (1982) has stated, a resistance against patriarchal injustice. The female welcoming of the other has been coextensive of women's historical task of providing care for others while they created a culture that has not been granted any moral nor epistemic authority:

Feminist thought has articulated a genealogy of care ... The ethos of care is a corpus of values, attitudes and practical behaviours oriented towards empathy and affection for the Other. ... The feminine ethics of care which, I insist, is not essential but historical, is not conceived as a moral principle like equality or freedom, because it is women's business and in a patriarchal society, women's businesses belong to the private space where moral principles that inform public questions are not discussed, including the social pact, understood as the agreement between moral subjects to regulate social life on the basis of certain principles. (Fernández Camacho 2016: 162-3, my translation)

The absence of a description of female spaces follows the pattern of a more general silence about women's historical and traditional ethical and epistemic production, which have been rendered as irrelevant or superfluous, both by modern secular culture and by the masculine, institutionalized religious establishment (see Starr-Sered 1990).

For Lévinas to exist is to dwell, and this dwelling is a 'recollection, a coming to oneself, a retreat home with oneself as in a land of refuge, which answers to a hospitality, an expectancy, a human welcome' (Lévinas 1969: 156). The home is a hospitable shelter from which we go into the world. The welcoming element is the core of the home, incarnated in the feminine.

Lévinas defined the feminine as the welcoming one par excellence, welcome in itself' (1969: 157). He argued that the home entails the relationship with the first alterity: the feminine (see Palaudarias 2014). Woman would be the other that fulfils the welcoming hospitality and whose presence is in fact an absence: 'the other whose presence is discreetly an absence, with which is accomplished the primary hospitable welcome which describes the field of intimacy, is the Woman' (Lévinas 1969: 155). There is an ambiguity in Lévinas about the metaphorical nature of the category 'woman' in his work, although he clarified that a home does not necessarily presuppose the presence of an empirical woman:

The feminine has been encountered in this analysis as one of the cardinal points of the horizon in which the inner life takes place - and the empirical absence of the human being of 'feminine sex' in a dwelling nowise affects the dimension of femininity which remains open there, as the very welcome of the dwelling. (Lévinas 1969: 158) 
In other words, femininity is an aspect of the human connected with dwelling and welcoming, but that does not require the presence, so Lévinas seems to say, of a woman. In a conversation between Bracha Ettinger and Lévinas, Ettinger interpreted Lévinas's approach to the feminine as reparative: 'For me, you restitute woman the things that had been taken from her: a certain symbolic principle of creation and an ethical space' (Lévinas and Ettinger 2005, my translation) ${ }^{14}$. Later on, Ettinger would write that femininity 'transforms from within what it means to be a subject, for it is the kernel of ethical being, the ultimate measure of the ethical relationship: [I] $t$ is that human possibility which consists in saying that the life of another human being is more important than my own' (Ettinger 2006: 189). Ettinger illustrates the idea of femininity as the very core of the ethical with a quote by Lévinas - taken from that same conversation I just referred to - in which he summarizes femininity as the human expression of selflessness.

However, I am uncomfortable with the abstraction and symbolism of these expressions. When Lévinas says that 'the woman is the condition for recollection, the interiority of the Home, and inhabitation' (1969: 155 ) it is hard to accept that he is not speaking about empirical women, actual women who actually have created this space of

14 The conversations were conducted between 1991-3 and were revised by both Lévinas and Ettinger for publication. The text from which this quote was selected was first published in 1993 in a limited edition called Time is the Breath of the Spirit, from Oxford's Museum of Modern Art. Unfortunately, I have been unable to access the English version of this conversation, as well as the original one in French. Therefore, this quote is my translation of the Spanish version done by Marta Palacio in 2005 . shelter, care, intimacy and recollection. In fact, if Ettinger is right about Lévinas's recognition of women's ethical space, there has to be a recognition that, historically speaking, empirical, and not metaphorical, women have crafted this space of the home and this ethical relation based on responsibility and care. This is not to say, of course, that women should remain exclusively within the contours of the home and care for others. Rather, that this space and practice deserves epistemic and moral authority.

\section{The ethics of care: a female contribution to our civilization's morality}

How can a female tradition of hospitality, with its practices of care, be reinvented without the violence within which it evolved? Can we rescue, preserve and honour a female ethics of hospitality as devotion to the other after a history of abuse and violence?

The emphasis on autonomy and independence of mainstream ethics in Western societies turns hospitality into a burden, and is therefore expressed most fully through mere gestures: for example, an invitation to have dinner at one's home. Some Western feminist discourses emphasize this ideal of autonomy, looking at care as unpaid work and a form of oppression, an unfair demand, an alienating task. But given the fact that not all members of society are free to decide whether they want to care for others, care becomes a commodity that can be purchased, marketed and sold, depending on one's purchasing power. Thus, the answer to the liberal aspiration to autonomy tends to be an immigrant woman who we pay to do the labour of care. Now the issue is what we lose, as a community, when we turn the question of care - taking responsibility for sheltering and nurturing others - into a question 
of freedom, autonomy and independence.

The liberal model of life is largely based on the pursuit of even more autonomy and career success. Burdens are tolerated as long as they contribute to an individual's own success and benefit. The example set by the mothers and the grandmothers shows us that in this liberal model the person needs to be burdened by responsibility if we are to live in community. Maybe he - since the normative person of neoliberalism is a man - needs to be challenged by the radical model of care that women have created. This model of care challenges the whole project of capitalism and the individualism it entails.

A society that wants us to be more autonomous, freer of responsibility, freer of the burden of others, is also a society in which nobody is willing to give up their autonomy and freedom to take care of us. But care cannot be cancelled. It will be done by someone underprivileged enough to be without a choice to decide whether she wants to take care of others or not.

The active practice of female hospitality - sheltering, nurturing, caring - is a moral contribution that is waiting for the recognition of its epistemic and moral legitimacy. Women have created an ethical paradigm of caring and being responsible for others that deserves something more than a critique of oppression and domination. Alba Carosio expressed in the following terms the function of social research in the context of South American feminisms:

The task is the articulation and clarification of the conditions in which the space of the social appears within these forms of domination: the space of a revindication of rights appears within the domination setting; in the lives of oppressed men and women appear moral seals such as hospital- ity and solidarity; within the settings of vulnerability, new forms of organized social action emerge, which entail the active agency behind the victim. Feminist thought has the capacity to modify visions and theoretical perspectives to create tools capable of approaching crucial issues of the real world in which we live, of human existence in all of its concrete determinations, of societies and their material organization. (Carosio 2017: 29, my translation)

Within conditions of inequality and violence, women have been caregivers. The ethical paradigm of care challenges the very foundation of individualism if we take it at face value, not as just as a burden that patriarchy has imposed on them. There is a feminine culture created over the generations among grandmothers, mothers, daughters, sisters, neighbours, friends who have resisted together and shared the labour of care. Feminine hospitalities include the domestic or everyday small services and gifts. Friendship and mutual support among women are domains where philosophical and literary traditions have developed. This is connected with everyday nourishment, both physical and emotional, of other women as well as other men.

\section{Arevot as a laboratory of hospitality: creating a different model of society}

In this section, I will present some fragments of interviews I have conducted since 2018 with different members of Arevot who are my partners in thought in this work. Most of the interviews took place in my home in Jerusalem, although some of them were held on videocall or at the homes of the interviewees. All the names are real, as per the request of the participants. I was the interviewer in all cases and the language of 


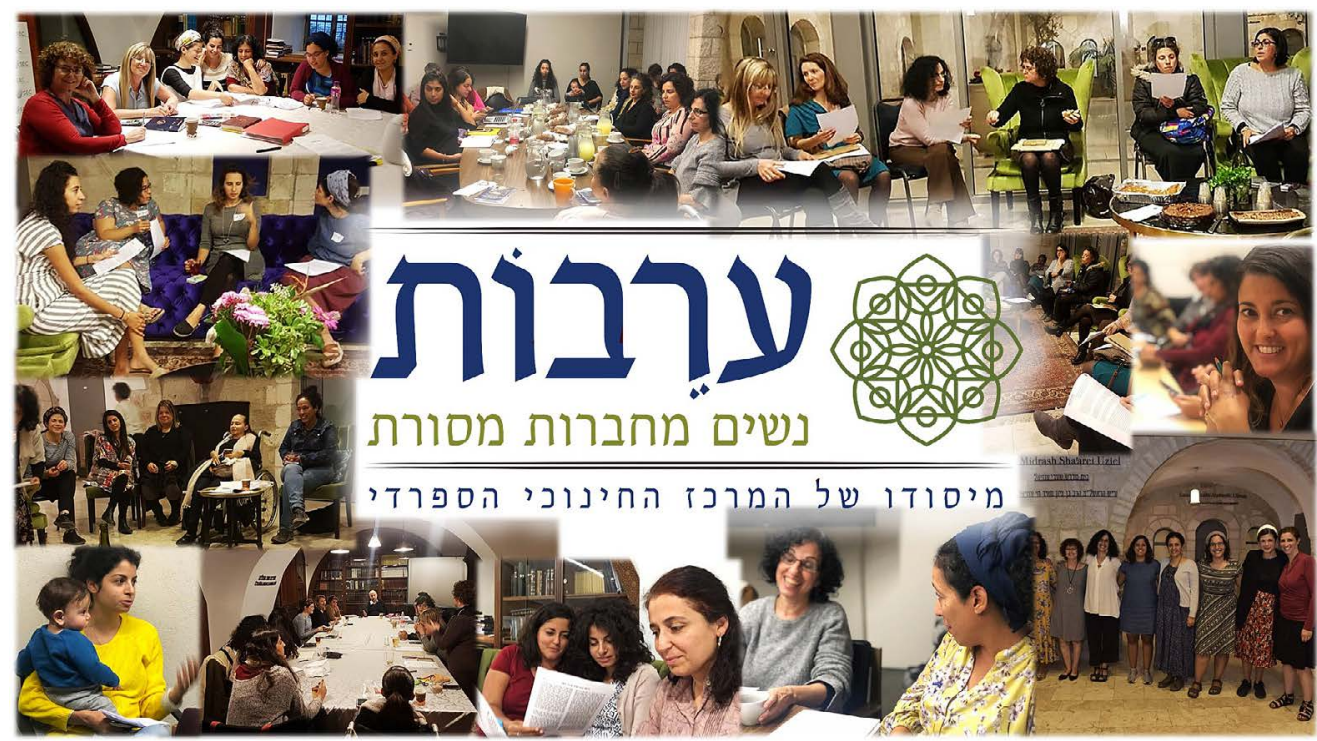

A collage by Sagy Watemberg from Arevot, with pictures of members and logo.

the conversations was Hebrew. All translations are mine.

The women of Beit Midrash Arevot enact the different elements of the female conceptualization of hospitality that I have discussed above. They are in the border zone between different worlds, and inhabit different tensions. The space of the home and the rituals learnt from mothers and grandmothers, along with the oral tradition, are part and parcel of the activities of these women. One of the principles of Arevot is the mutual responsibility among the members, beyond ideological, cultural or religious differences. The very name 'Arevot' is connected to the root arev (ערב) in Hebrew and has different meanings that connect with Arevot's purposes: responsibility for each other and for the whole of society, a weaving together of tradition and social involvement. The values typically attributed to traditionalism (moderation, flexibility, inclusion, loyalty, etc.; see Buzaglo 2008) are part of a feminism committed to the Sephardi tradition in a way that demands the changes we need in order to continue to feel part of this narrative. Finally, in Arevot, there is total respect for the idea that hospitality does not ask questions to the stranger in order for her to be integrated and accepted.

The women of Arevot want to provide a home from which to reclaim epistemic and moral authority, from which to challenge an authority that keeps women away from knowledge of their own cultural traditions, be it in the name of secularism, feminism or even in the name of the Mizrahi struggle. Shira Ben Eli, lawyer and legal assistant at the Rabbinic Court in Jerusalem:

First, we are a group of feminist women, but we are inside a complexity that is in dialogue with the masculine world, understanding that they're also in a process and that it's hard for them to swallow the feminine world ... The Mizrahi struggle, which is mainly masculine, is important, that will exist and we are in conversation with them, but if we're in it, we will disappear, but we don't want to disconnect 
ourselves from it. We are all the time in conversation with all the different worlds, because the connection is important for us. It is very important for us. But we know that if we don't do it separately, we will disappear. We will either disappear amidst the white religious feminists, or amidst the Mizrahi struggle. So, our position is that the relations are important, but to exist we need to be separate.

Arevot is reconstructing the language of the women that preceded us along with the recovery of the teachings of Sephardi and Mizrahi sages. This is the meaning of traditionist feminism, which is more multicultural than universalistic and differs from Western feminism in its assertion of tradition. Osnat Bensoussan, chazanit 15 , paytanit ${ }^{16}$ and co-leader of the Sephardiegalitarian congregation Degel Yehuda in Jerusalem, put it in these terms:

In one of the meetings of our first or second year, we had a conversation and there were questions, one of which was whether or not you define yourself as a feminist. And the answer of most women in the group was 'no, I am not a feminist' ... Because, for us, the word 'feminism' comes with a very big erasure of our cultural and emotional baggage. It means that now we are supposed to go against not only patriarchy and male dominance, but also against everything that was brought by them. But we want to remain within that world, within our tradition, with the customs of our mothers, and we want to grow within it, we don't want

15 Chazanit: female liturgical cantor.

16 Paytanit: female performer of liturgical and traditional songs. to draw a line, we don't want to break with it. Thus, one of the differences is that we come from an awareness of completeness. We don't need to have a feminist revolution to feel that we are doing something in the world. It's not our emphasis. If anything, we want to come from within the world we grew up in, from a place of respect and love - a lot of love for our parents and the things we learnt in their home - and we want to grow with this. So, for us, this means to go to these texts and learn the texts and the sages and thoughts, with that baggage, not to disconnect, not to lose the relationship. The connection with that world is critical, in our experience.

Western postmodern conceptualizations of feminism and the secularizing inclination have an oppressive effect when your struggle is against oblivion and cultural erasure as much as it is against patriarchy. Pazit Adani, educator and activist, put it in these terms:

They cancel you from their postmodernism and you just don't understand what your problem is with a criticism whose foundations are very liberal. And it kills you. ... By the end of my academic years I was empty. It's a very critical thought that emptied me. ... White feminism is very critical, very deconstructive, less loyal ... Very radical, an analysis of power relations and that's it. Men, women, how women are oppressed ... which worked for me, but still it wasn't complete. Something there wasn't mine. So I arrive at Mimizrah Shemesh ${ }^{17} \ldots$ And with the

17 MiMizrach Shemesh is a Beit Midrash and organization located in Jerusalem that 
shock from the texts, tough texts, and Gemara ${ }^{18}$, and I have my own traumas, from the Judaism that I learnt in the boarding school, how they made me hate religion. But all of a sudden, it's soft ... And slowly I understand that I'm sitting with Talmidei chacha$\mathrm{mim}^{19}$. And I keep quiet. A silence of shock, but also respect and the understanding that there is something I don't know. But it's huge. And I want to know, and I want to understand. Because I believe in them ... All of a sudden in the learning of the Torah, all the connections, all the identities, come together. And something in me was softened ... and the narratives softened, they're closer to this thing of mine that is called Jewish-MizrahiIsraeli-peripheral, identity.

Learning the Torah from the perspective of the Sephardi sages makes it possible to imagine a feminism that speaks the language of our parents and grandparents, while we look for the specific voice of women. It unites the search for social justice with the recovery of a cultural memory that was erased by both Western secularism and the Ashkenazi establishment. Zehorit Asulin, a clinical psychologist, expressed the importance of this recovery as follows:

This is part of our intellectual wealth. Part of our intellectual wealth existed through religious thought. Afterwards

trains leaders and activists to engage in social justice grounded in the teachings of Sephardi thinkers and sages.

18 Gemara: commentary on the Mishna, the first major compilation of rabbinic literature. Both the Mishna and the Gemara constitute the Talmud.

19 Talmidei chachamim: literally, 'students of sages'. also modern Jewish intellectuality was developed, inspired by colonialism and the French and Jewish intellectuals ... Now, as someone who is active in Metaksot $^{20}$, I feel that the question of the Torah of the mother that was passed on through practice, orally, not from some sort of great depth, but still there is something that sustains the quality of the ritual ... In rituals, there is the depth of the bond, of belonging. I wanted to give place to this ... Arevot fulfils a very strong spiritual need ... It's something spiritual, intellectual and also a feeling of being home.

Inclusiveness is a central value of this movement of traditionist feminism, which does not require a complete alignment with a set of principles. In this sense, flexibility and welcoming of otherness is critical. Educator Shlomit Boni reflects on this:

Arevot has the ability to contain contradictions. It includes complexity, in an authentic way, not in an abstract way. I can be in Arevot and not be part of an egalitarian minyan [prayer group]. And this does not take anything away from my feminism, from my commitment to the idea of women learning the Torah, or women developing their own way. I am not measured according to the level of my commitment to feminism. [In Arevot] I can have another value system that is also legitimate. I don't need to be ashamed of it. Whether it's in the clothing, whether it's in the tefilot [prayers], as I said, even if it's in the attitude towards relationships. I can have a very trad-

20 Metaksot: a group within Arevot that reclaim and renovate Jewish rituals with an emphasis on female rituals. 
itional attitude towards relationships, for example, and I still will be very feminist, and it will match together.

Shlomit is highlighting a particularity of hospitality: not to ask too many questions, to refrain from the desire to categorize and thereby to force the other to function on our terms. Ambiguity and openness to contradiction and to competing moral codes, are part of hospitable reception of the other. In the words of Derrida:

Shouldn't we also submit to a sort of holding back of the temptation to ask the other who he is, what her name is, where he comes from, etc.? Shouldn't we abstain from asking another these questions, which herald so many required conditions, and thus limits, to a hospitality thereby constrained and thereby confined into a law and a duty? (Derrida 2000: 135)

Hospitality relates to difference and that which unsettles us. It is the reception of another that might not have a name entered onto our list of categories. The ability not to ask too many questions, to stay with the ambiguity of the other, his or her undefinition, is one of the requirements of hospitality.

Hospitality is our response to the stranger. The stranger is someone who is not directly related to us and yet we have a responsibility towards him or her. Yafa Benaya, researcher, activist, and member of Degel Yehuda, describes this in the following terms:

I see Arevot as a small reproduction of the communities of our countries of origin [in the north of Africa and the Middle East]. Not everybody were friends, but there was a type of acceptance ... a community that has some unity. And this unity is very important. As an example, we have a Conservative ${ }^{21}$ Rabba [female rabbi], we have secular, religious, leftwing, right wing, Ashkenaziot and Mizrahiot ... There are members who are not pro-egalitarian tefilah [collective prayer]. Which is absolutely fine! We are not Conservative, nor Reform, that's not our story! This is what I mean: to try to reproduce our original communal ethos.

Yafa Benaya is arguing for an alternative to the concept of 'community' as an interest group. She is presenting a philosophy of hospitality that advocates a way of being with the other facing his or her total otherness. This is an alternative that certainly makes life less comfortable, but might make others more morally reliable. She is also defending a model of diversity that is capable of holding ideological disagreement.

Heftsi Cohen-Montagui, editor and translator, activist and former co-leader of Degel Yehuda, reflects about the potential effects of feminism in dismantling the ethics of care:

When we, in Arevot, make a change we don't only think 'is equality for women necessary? It is.' Of course, it is. But what happens when we apply the practices that bring equality? What happens to the community fabric, to

21 Conservative Judaism is one of the denominations in which Ashkenazi Jewry is organized (or split, depending on how we choose to look at it). It is situated on the more liberal side of the spectrum and advocates for egalitarianism in the liturgical practices as well as for the relaxation of certain dietary laws and laws of Shabbat, among others. 
the family, what happens to men, what happens to the culture... meaning, our way of thinking about this goes beyond the discourse about rights... For example, there are many men who don't agree with how I developed my feminism in the synagogue. But it doesn't mean that I won't take them into account. Even though they don't agree with me. On the other hand, I won't give myself up, because I'm also part of this story.

These are the most appropriate words to close this essay, as they return us back to one of the main concerns I have shared with the reader: the consequences of assuming the male and liberal model of autonomy which turns care into a burden and the welcoming of the other into nothing more than a sporadic invitation to visit us in our home. Heftsi Cohen-Montagu is reflecting about the implications of equality in a world which continues to assume that the historical experience of women as caregivers and mothers does not have any epistemic or moral authority. A world that continues to see those tasks as worthless and, therefore, oppressive.

As I stated at the beginning of this essay, there is a model of civilization that is waiting to be articulated and granted authority. A different model of society that challenges the dichotomies of domestic-public, responsibility-freedom, care-autonomy, scientific-popular, religion-rationality which underpin the female-male dichotomy.

At this point, I am thinking of Hélène Cixous and her critique of the way in which woman "has always functioned "within" the discourse of man, a signifier that has always referred back to the opposite signifier which annihilates its specific energy and diminishes or stifles its very different sounds' (Cixous 1976: 887). Cixous states the need 'for her to dislocate this "within," to explode it, turn it around, and seize it; to make it hers, containing it, taking it in her own mouth, biting that tongue with her very own teeth to invent for herself a language to get inside of' (ibid.). Arevot's work is this biting of our tongues to find that language inside of which we could get and welcome others.

Dr Angy Cohen is the 2019-20 postdoctoral fellow at the Azrieli Institute of Israel Studies at Concordia University and the 2020-1 Belzberg Postdoctoral Associate in Israel Studies at University of Calgary. Her research is focused on the construc-

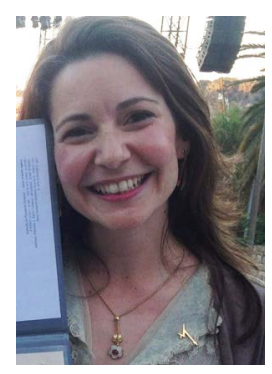
tion of identity and memory among Jews from Moroccan in Israel. She received her PhD in 2017 from the Hebrew University of Jerusalem, Israel and the Universidad Autónoma of Madrid, Spain in a joint PhD program. Her doctoral dissertation was a comparative ethnographic study of life stories among Spanish-Moroccan Jews that emigrated to Israel and Argentina. In 2018-19 she was a postdoctoral fellow at Tel Aviv University, where she researched autobiographical narratives of second-generation Moroccan activists in Israel. In the last two years, she has expanded her research to the exploration Beit Midrash Arevot as a model of Sephardi/Mizrahi traditionist feminism.

\section{References}

Barroso, José María. 2016. 'Descolonizando. Dialogo con Yuderkis Espinosa Minoso y Nelson Maldonado-Torres', Iberoamérica Social: Revista de estudios sociales, 6: 8-26.

Buzaglo, Meir. 2008. A Language for the Faithful: Reflections on Tradition (Jerusalem: Mandel Foundation) [in Hebrew].

Carosio, Alba. 2017. 'Perspectivas feministas para ampliar horizontes del pensamiento crítico latinoamericano, in Feminismos, pensamiento crítico y propuestas alternativas en América Latina, coord. Montserrat 
Sagot Rodríguez (Buenos Aires: CLACSO), 17-42.

Cixous, Hélène. 1976. 'The laugh of the Medusa, Signs, 1(4), <https://doi. org/10.1086/493306>.

Derrida, Jacques. 2000. Of Hospitality: Anne Dufourmantelle invites Jacques Derrida to Respond, trans. Rachel Bowlby (Stanford University Press).

Duran, N. 2005. 'Having men for dinner: deadly banquets and biblical women', Biblical Theology Bulletin, 35(4): 117-24, doi: <https:// journals.sagepub.com/doi/abs/10.1177/014 61079050350040101>.

Elbaz, Vanessa Paloma. 2018. 'KOL B'ISHA ERVA: the silencing of Jewish women's oral traditions in Morocco', in Women and Social Change in North Africa: What Counts as Revolutionary? eds. Dorys H. Gray and Nadia Sonnenveld (Cambridge University Press), 263 s88.

Espinosa-Miñoso, Yuderkys. 2014. 'Una crítica descolonial a la epistemología feminista crítica', El Cotidiano, 184: 7-12.

Estalella, Adolfo, and Sánchez-Criado, Tomás. 2018. Experimental Collaborations: Ethnography through Fieldwork Devices (Oxford: Berghahn).

Ettinger, Bracha. 2006. The Matrixial Borderspace (Minneapolis: University of Minnesota Press).

Fernández Camacho, Marcela. 2016. 'El cuidado como principio moral universalizable, Revista de Derechos Humanos y Estudios Sociales, 8(16): 153-69.

Gilligan, Carol. 1982. In a Different Voice: Psychological Theory and Women's Development (Cambridge, MA: Harvard University Press).

Gudme, A. K. 2014. 'Inside-outside: domestic living space in biblical memory', in Memory and the City in Ancient Israel, eds. Diana V. Edelman and Ehud Ben Zvi (Winona Lake, IN: Eisenbrauns), 61-78.

- - 2019. 'Death at the hand of a woman: hospitality and gender in the Hebrew Bible, in Gender and Methodology in the Ancient Near East, ed. S. Lynn Budin, Barcino. Monographica Orientalia, 10 (Universitat de Barcelona Edicions), 23-33.

Hamington, Maurice. 2010. 'Toward a theory of feminist hospitality', Feminist Formations,
22(1): 21-38, doi: <https://www.jstor.org/ stable/40835342?seq=1\#metadata_info_ tab_contents $>$.

Hasan-Rokem, Galit. 2014. 'Bodies performing in ruins: the lamenting mother in ancient Hebrew texts', in Lament in Jewish Thought: Philosophical, Theological and Literary Perspectives, eds. Ilit Ferber and Paula Schwebel (Berlin: De Gruyter), 33-64.

Lévinas, Emmanuel. 1969. Totality and Infinity: An Essay on Exteriority (Pittsburgh: Duquesne University Press).

Lévinas, Emmanuel, and Bracha Ettinger. 2005. 'Qué diría Eurídice. Emmanuel Levinas en conversación con Bracha LichtenbergEttinger', trans. Marta Palacio, Anatellei, 13: 63-73.

Madar, Vered. 2014. 'Women's oral laments. Corpus and text: the body in the text', in Lament in Jewish Thought: Philosophical, Theological, and Literary Perspectives, eds. Ilit Ferber and Paula Schwebel (Berlin and Boston: De Gruyter), 65-86.

Matthews, Victor. 1991. 'Hospitality and hostility in Judges 4', Biblical Theology Bulletin, 21(1): 13-21, doi: <https://doi.org/10.1 177/014610799102100103>.

- - 1992. 'Hospitality and hostility in Genesis 19 and Judges 19', Biblical Theology Bulletin, 22(1): 3-11, <https://doi.org/10.1177/0146 $10799202200102>$.

Palaudarias, Andrea. 2014. 'La casa como umbral de la trascendencia. Interioridad y economía en Emmanuel Lévinas', Master's thesis, Universitat de Bacerlona.

Pedaya, Haviva. 2019. Island M. (Tel Aviv: Yediot Sefarim) [in Hebrew].

Pitt-Rivers, Julian. 1968. 'The stranger, the guest, and the hostile host', in Contributions to Mediterranean Sociology, ed. J. G. Peristiany (Paris: Mouton), 13-30.

- - 2017a. 'The place of grace in anthropology', in From Hospitality to Grace: A Julian Pitt-Rivers Omnibus, eds. Giovanni da Col and Andrew Shryock (Chicago, IL: Hau), 69-104.

- - 2017b. 'The law of hospitality', in From Hospitality to Grace: A Julian Pitt-Rivers Omnibus, eds. Giovanni da Col and Andrew Shryock (Chicago, IL: Hau), 163-84.

- 2017c. 'Women and sanctuary in the 
Mediterranean', in From Hospitality to Grace: A Julian Pitt-Rivers Omnibus, eds. Giovanni da Col and Andrew Shryock (Chicago, IL: $\mathrm{Hau}), 185-98$.

Ruddick, Sara. 1995. Maternal Thinking: Toward a Politics of Peace (Boston: Beacon Press).

Sagot Rodríguez, Montserrat. 2017. 'Introducción', in Feminismos, pensamiento crítico y propuestas alternativas en América Latina, coord. Montserrat Sagot Rodríguez (Buenos Aires: CLACSO), 9-16.

Sanders, Jennifer P. 2004. 'Portrayals of the unnamed concubine (Judges 19) in early Jewish literature', Master's thesis, McMaster University, <https://macsphere.mcmaster. $\mathrm{ca} /$ bitstream/11375/13601/1/fulltext.pdf $>$ (accessed 31.8.2020).

Starr-Sered, Susan. 1990. 'Women, religion, and modernization: tradition and transformation among elderly Jews in Israel', American Anthropologist, 92(2): 306-18.

- -1992. Women as Ritual Experts: The Religious Lives of Elderly Jewish Women in Jerusalem (New York: Oxford University Press).

Trible, Phyllis. 1984. Texts of Terror: Literary-Feminist Readings of Biblical Narratives (Philadelphia: Fortress Press). 